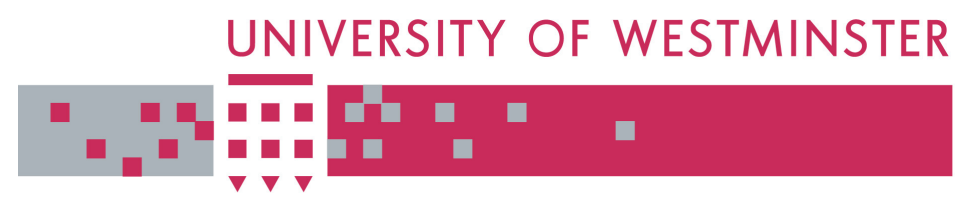

WestminsterResearch

http://www.wmin.ac.uk/westminsterresearch

\title{
The road to military humanitarianism: how the human rights NGOs shaped a new humanitarian agenda
}

\section{David Chandler}

School of Social Sciences, Humanities \& Languages

Chandler, David C. The Road to Military Humanitarianism: How the Human Rights NGOs Shaped a New Humanitarian Agenda. Human Rights Quarterly 23:3 (2001). 678-700. (C) The John Hopkins University Press. Reproduced with permission of the John Hopkins University Press.

The WestminsterResearch online digital archive at the University of Westminster aims to make the research output of the University available to a wider audience. Copyright and Moral Rights remain with the authors and/or copyright owners. Users are permitted to download and/or print one copy for non-commercial private study or research. Further distribution and any use of material from within this archive for profit-making enterprises or for commercial gain is strictly forbidden.

Whilst further distribution of specific materials from within this archive is forbidden, you may freely distribute the URL of WestminsterResearch.

(http://www.wmin.ac.uk/westminsterresearch).

In case of abuse or copyright appearing without permission e-mail wattsn@wmin.ac.uk. 
Forthcoming in Human Rights Quarterly, Vol. 23, No. 3, August 2001

\section{The Road to Military Humanitarianism: How the Human Rights NGO's Shaped A New Humanitarian Agenda}

\section{Introduction}

The transformation of humanitarianism from the margins to the centre of the international policy-agenda has been achieved through the redefinition of humanitarian policy and practice and its integration within the fast-growing agenda of human rights. The new international discourse of human rights activism no longer separates the spheres of strategic state and international aid from humanitarianism, but attempts to integrate the two under the rubric of 'ethical' or 'moral' foreign policy. As the humanitarian NGOs have been integrated into policy-making forums, the policymakers have increasingly claimed to be guided by humanitarian principles.

The human rights NGOs, in conjunction with governments and international institutions, have established a rights-based 'new humanitarian' consensus, which has succeeded in redefining humanitarian policy. The universal principles, which defined the early humanitarian internationalists, are now widely criticised by their NGO successors as the language of universal humanitarianism has been reworked to pursue human rights ends. The 'new humanitarians' assert that their ambitious strategic ends inevitably clash with their earlier principles, which developed in an age when it was necessary to obtain the consent from states, in which they operated, and the opportunities for more long-term involvement were limited. Today, not only is this more interventionist approach seen as a legitimate response to humanitarian crises in non-Western states, it is increasingly understood to be non-political and ethically driven.

This paper is concerned with the process through which the core ethics of humanitarianism have been transformed, focusing on the shift in the politics of humanitarian interventionism as advocated by non-governmental organisations during and after the Cold War. It considers the non-political approach of traditional humanitarian organisations and the development of more politicised human rightsbased humanitarian NGOs, it further analyses some of the consequences of this change, the retreat from the principles of neutrality and universalism and the development of 'military humanitarianism'.

\section{Humanitarian universalism}

The organisation that over the last century has most epitomised the values of humanitarian universalism has been the Red Cross. The Red Cross established that humanity, impartiality, neutrality and universality were the underlying principles of any humanitarian intervention. The principle of humanity was based on the desire to assist the wounded and suffering without discrimination, recognising a common humanity and that 'our enemies are men'. The principle of impartiality derived from the desire to assist without discrimination except on the basis of needs, giving priority to the most urgent cases of distress. The principle of neutrality bound Red Cross workers from taking sides in conflict or engaging in political or social controversies. 
The principle of universality claimed that the ICRC approach was the same the world over on the basis that the humanitarian values were shared universally. These four principles were predicated on separating the humanitarian sphere from the political one. ${ }^{1}$

The avoidance of politics was essential to the definition of humanitarianism. Cornelio Sommaruga, President of the ICRC, in his speech to the UN General Assembly, in November 1992, made this clear: 'Humanitarian endeavour and political action must go their separate ways if the neutrality and impartiality of humanitarian work are not to be jeopardised. ${ }^{2}$ Jean Pictet, one of the ICRC's leading thinkers warned that 'Red Cross institutions must beware of politics as they would of poison, for it threatens their very lives'. ${ }^{3}$ As Michael Ignatieff notes, humanitarianism was the core of the ICRC's non-political outlook: 'It made no distinction between good wars and bad, between just and unjust causes, or even between aggressors and innocents'. ${ }^{4}$

Amnesty International, founded in 1961 with the aim of working for the release of 'prisoners of conscience', similarly pursued a universal campaign for the rights of political prisoners, regardless of whether they were persecuted by US or Soviet backed regimes. The politics of the prisoners were irrelevant, what mattered was that they were held for their religious, political or other consciously held beliefs or by reason of their ethnic origin, gender, colour or language. As well as working for the release of political prisoners, Amnesty also campaigned against capital punishment and the use of torture or inhuman punishment in all cases, not just for political prisoners. Amnesty was not concerned with the politics or beliefs of the prisoners but with all prisoners receiving a minimum of universal standards of treatment.

The United Nations also established institutions solely for the purpose of humanitarian aid, such as the UN Relief and Rehabilitation Administration (UNRRA) 1943-7, the UN International Children's Emergency Fund (UNICEF) in 1946 and the UN High Commissioner for Refugees (UNHCR) in 1950. The mandates of these institutions were explicitly humanitarian, not political. Private charity organisations were also involved in famine relief, many having been founded in response to the First and Second World Wars. Save the Children Fund was established in the aftermath of the First World War. Oxfam was founded in 1942, initially as the Oxford Committee for Famine Relief, providing relief for the famine victims in Germanoccupied Greece. These relief aid charities, like the ICRC, saw themselves as filling the gaps of humanitarian need that temporarily, in the aftermath of war, could not be met through the political system. By the end of the 1940s the major relief charities established themselves in a more permanent role, not merely addressing wartime distress but international suffering in the developing world.

During the Cold War, the work of relief charities achieved a high profile precisely because of their universalist approach and political neutrality. They played an important role in providing aid where the international geo-political divide meant leading Western states were not willing to assist those in need. The Biafra crisis in 1968 was one of the first examples of humanitarian aid NGOs mobilising in the face of British and international disapproval. In the 1970s NGO relief intervention was repeated in Bangladesh, Ethiopia, the West African Sahel and Cambodia after the defeat of the Khmer Rouge government. In all these cases the NGOs campaigned against the lack of official institutional intervention. While the major powers pursued 
the realpolitik of the Cold War, humanitarian NGOs showed up the gaps in humanitarian needs. The non-governmental nature of NGOs meant that they could operate despite political pressure, as Ben Whittaker notes, these cases demonstrated that Oxfam and other NGOs could 'operate where huge governments and international bodies were stymied as politically hamstrung, ${ }^{5}$

This position gave humanitarian NGOs a radical edge, putting the interests of people above the strategic concerns of the East/West divide and providing aid against the wishes of Western governments. Agencies such as Oxfam, Impact, Concern and Save the Children Fund became popularly identified with the pro-Third World cause, providing these previously staid organisations with a new more youthful and popular appeal. The high-point of NGO humanitarianism came with the Live Aid campaign to raise funds for the Ethiopian famine of 1984-5. The aid agencies, in collaboration with Bob Geldof's Live Aid, were instrumental in defying the indifference of Western governments and launched a hugely popular relief campaign. ${ }^{6}$ Most importantly, relief aid was avowedly non-political, there were no strings attached. Relief NGOs did not seek to link aid to specific Western states or to dictate economic or social policy. Humanitarian relief was assumed to be given free of political conditions or association with foreign or defence policy, delivered purely on the basis of need. As Bruce Nicholls summarises: 'the two principles of nondiscrimination and political neutrality pervade both Geneva Law and the public face of modern humanitarianism. Without them, humanitarian practice would be indistinguishable from partisan political activity'?

For most of the Cold War period the division between state-led development aid, open to political considerations, and politically-neutral humanitarianism was clear and transparent. Particularly in the 1960s and 1970s, the problems of war and famine in the non-Western world were predominantly seen in the context of Western domination and Cold War clientelism. The existence of broad social and political movements based on Third World solidarity or critiques of Western market domination meant that the problems were seen in a broader international context. It was this broader focus on the relationships of power and dependency that meant that the potentially patronising aspects of charitable aid were contained and, at least publicly, there was little support for blaming or condemning aid-recipients nor the non-Western governments facing a humanitarian crisis.

\section{Beyond humanitarianism}

Until the early-1990s the ICRC had a monopoly on the definition and elaboration of humanitarian principles. ${ }^{8}$ Since then there has been a proliferation of doctrinal changes, led by pressure from 'new humanitarian' NGOs and institutional funders. For example, the 1994 Red Cross/NGO Code of Conduct, 1993 Providence Principles and the 1993 Mohonk Criteria. There are two strands to the 'new humanitarian' approach that predate the post-Cold War changes. The first strand, developed in response to conflict situations, was the extension of involvement from the provision of immediate assistance to victims of conflict to the greater commitment of solidarity and advocacy work for victims and concerns for the long-term protection of human rights for 'at risk' groups. The second strand, which developed in response to problems of famine and drought, was the move of relief NGOs from emergency humanitarian aid to long-term developmentalism in the 1970s. 
Both these strands have sought to move beyond the traditional non-strategic humanitarian aims of saving human lives and reducing human suffering. The gradual build-up of pressure to aspire to achieve longer-term policy ends has reflected the changing perceptions of the NGO role in international situations and the increasing support for a more extensive rights-orientated involvement. Nicholas Leader, from the Overseas Development Institute, categorises these two challenges to the ICRC's principles as 'deepening' and 'broadening' the conception of humanitarianism. The NGOs who want a more committed 'solidarity' form of intervention in conflict situations have emphasised the need for protection or security as well as assistance. The developmental NGOs have argued that humanitarian intervention should also include long-term assistance such as peace-building, capacity-building, empowerment and development as reflected, for example, in the Mohonk Criteria. ${ }^{9}$

Once the 'new humanitarian' NGOs focused on solidarity or long-term development it became necessary to make strategic choices regarding which aims to prioritise and which groups to work with. The desire to politicise involvement in aid provision without sacrificing their neutral and 'non-political' status, led NGOs to seek to justify their strategic choices through the language of morals and ethics rather than politics. It was this conflict between evolving policy practice and the traditional humanitarian basis for involvement that laid the basis for the human rights discourse of today. The humanitarian NGOs were the first international organisations who sought to use the terminology of human rights in an attempt to justify political policy choices in the language of ethics:

The ethical basis for making choices...is often a far more complex and political decision as it implies decisions about rightness and just causes... If the principle of impartiality is rejected, who is to judge which is which? This is sometimes termed a shift from a needs-based to a rights-based humanitarianism. In many ways the deeper notion of humanitarianism that includes both protection and assistance is a rights-based humanitarianism. ${ }^{10}$

\section{Deepening humanitarianism}

The birth of the modern human rights-based 'solidarity' movement has often been located in NGO responses to the Biafran famine in 1968. ${ }^{11}$ The famine resulted from the independence war fought by Igbo secessionists of Biafra state in south-eastern Nigeria against the Federal Government. The secessionist struggle received no diplomatic support from the West, the Soviet bloc or other African states, which were concerned over the destabilising effects of questioning state borders. Within a few months the dominance of the government forces and the lack of outside aid had doomed the struggle to failure. As Alex de Waal notes, it was only by accident that Biafra became a cause celebre for the human rights movement. The international attention stemmed from the famine becoming news through the publication of photographs of severely malnourished children.

The media coverage, of the first African famine to become headline news, led to accusations that the British governments' arms shipments to the Nigerian leadership and lack of support for the Biafrans was making it complicit in genocide by starvation. The lack of UN or outside government relief for the secessionists enabled 
the humanitarian aid effort to be monopolised, for the first time, by the NGOs. Biafra was the ICRC's first large-scale relief operation and Oxfam's second field operation. The first real test for non-government humanitarian organisations resulted in a split between the ICRC and major NGOs over the nature of humanitarian action. Oxfam broke its commitment not to act unilaterally and took an openly partisan approach claiming that 'the price of a united Nigeria is likely to be millions of lives'. ${ }^{12}$ Several international NGOs followed, arguing that breaking from the ICRC position of noncriticism was the only ethical way of assisting the population because if the Biafran people lost the struggle for secession they would face systematic massacre by Federal forces.

The NGOs and the church-funded campaigns became the main propagandists, and source of international support, for the Biafran struggle. The Joint Church Airlift supplied aid and attempted to establish a Biafran air force, against Nigerian government opposition. This led to a federal ban on outside aid flights. The ICRC did not engage in any publicity and accepted the federal government's ban on aid flights, and was condemned by the more interventionist and partisan aid NGOs. A leading critic was French doctor Bernard Kouchner, who resigned from the ICRC, declaring that their silence over Biafra made its' workers 'accomplices in the systematic massacre of a population'. ${ }^{13}$ In 1971 Bernard Kouchner established Médecines sans Frontières (MSF), which has since symbolised the 'new humanitarian' cause. There are two 'solidarity' principles, which were developed out of the Biafra experience and have since become central to the new rights-based humanitarianism. Firstly, the 'freedom of criticism' or 'denunciation'. As James Orbinski stated, on accepting the 1999 Nobel Peace Prize on behalf of MSF:

Silence has long been confused with neutrality, and has been presented as a necessary condition for humanitarian action. From its beginning, MSF was created in opposition to this assumption. We are not sure that words can always save lives, but we know that silence can certainly kill. Over our 28 years we have been - and are today - firmly and irrevocably committed to this ethic of refusal. ${ }^{14}$

Secondly, the 'subsidiarity of sovereignty' or the 'right of intervention', the 'sans frontières' of the MSF movement. Many commentators have cited MSF founder and future United Nations Governor of Kosovo, Bernard Kouchner, as the humanitarian official responsible for popularising the legal theory of French academic Mario Bettati, who developed the concept of the 'right of intervention'. ${ }^{15}$

Both these 'new humanitarian' principles challenge the ICRC work which depended on the consent of the parties in the area in which it worked. This invasive approach of 'solidarity' has received wide support, particularly since the end of the Cold War. As George Foulkes states: 'Humanitarianism...demands that we stand firmly alongside those striving against oppression, and assist their struggle for dignity and basic human rights'. ${ }^{16}$ However, the NGOs which choose to engage in advocacy and solidarity are of necessity eroding the principles of needs-based humanitarianism by subordinating needs to the strategic ends of human rights and the struggle against oppressive Third World governments. ${ }^{17}$ 


\section{Broadening humanitarianism}

The 1970s and 1980s saw the direct government funding of NGOs like Oxfam, Christian Aid and CAFOD, the integration of international humanitarian NGOs in international institutions and their growth in numbers and influence. International NGOs were increasingly relied upon to administer government and institutional relief funds in disaster situations in the 1980s. By the mid-eighties 70 percent of UK aid to Sudan and 50 percent of British relief to Ethiopia was managed through NGOs. As they received wider recognition and took on greater responsibilities towards aiding the Third World, they began to look at their own work in a more critical fashion. Many aid agencies became dissatisfied with the limited impact of relief aid on the plight of people in the developing world.

In order to address the problems of the Third World, the more radical NGOs turned to development, and argued for a long-term involvement in the South rather than shortterm emergency aid. Most of the international agencies took up the Freedom from Hunger campaign maxim: 'Give a man a fish and you can feed him for a day. Teach him to fish and you feed him for life'. ${ }^{18}$ By the end of the 1970s Oxfam was spending less than ten percent of its budget on emergency relief and over 50 percent on development issues. ${ }^{19}$ However, by the late 1970s it was becoming increasingly clear that the state-led development strategies of the South were having little success. While a few commentators located the problems of development in the context of inequalities promoted by the world market system most drew the lesson that Third World states could not be trusted to pursue development.

The humanitarian agencies campaigned against much of the international developmental aid for Southern states, arguing that, in the Cold War context, Western powers were more interested in shoring up corrupt elites than tackling poverty. While US diplomats focused on people suffering under communist regimes, humanitarian NGOs criticised US development aid for authoritarian regimes in Africa and Latin America. ${ }^{20}$ State-led aid programmes were seen during the Cold War as tainted by superpower geo-politics, with no examples of purely humanitarian actions. As US President Nixon openly stated in 1968: 'the main purpose of American aid is not to help other nations but to help ourselves'. ${ }^{21}$ While the superpowers and state-staffed UN agencies may have shared the language of human rights and development aid with the NGO community, there was little in the way of shared assumptions and they were staffed by different kinds of people. ${ }^{22}$

In opposition to the development policies pursued by non-Western states, international NGOs focused on alternative grassroots models of development. This approach is explained up by David Korten, a former worker for the US Agency for International Development (USAID):

The wide spread belief that development is primarily a task of government has legitimised authoritarianism and created major barriers to true development progress in the South and over the past four decades the people have been expected to put their faith and resources in the hands of government. In return governments have promised to bestow on the people the gift of development. This promise has proved a chimera born of a false assessment of the capacity of government and the nature of development itself. ${ }^{23}$ 
As Southern states were crippled by the debt crisis and later by the World Bank structural adjustment programmes, state provision of welfare collapsed in many societies. International relief NGOs, with Western government funding, attempted to fill in the gaps. As two Oxfam workers explained:

Gallantly stepping into the breach come the NGOs very much in the neocolonial role. Whole districts, or once functioning sections of government ministries, are handed over to foreigners to run especially in health or social services. This process is enhanced as Structural Adjustment Programmes bite even deeper...40 percent of Kenya's health requirements are now provided by NGOs... The more the NGOs are prepared to move in the easier it is for government to reduce support. ${ }^{24}$

In fostering 'people-focused' approaches to development, focusing on projects which attempted to help the poorest sections of society, the international NGOs developed the concepts of 'capacity-building', 'empowerment' and 'civil society' as they argued the need for a long-term involvement in society and a sphere of influence independent from the Third World state. As Edwards and Hulme note:

NGOs and GROs [grassroots organisations] have been awarded a key role in this process by donor agencies, and are seen as an integral component of a thriving civil society - an essential counterweight to state power, opening up channels of communication and participation, providing the training ground for activists, and promoting pluralism. ${ }^{25}$

In the mid- and late-1980s NGOs were encouraged to establish new indigenous NGOs in the South, which increasingly received direct funding. These Southern 'partners' allowed Western donors to create parallel structures of aid and relief distribution which further acted to undermine and delegitimise the already weak and underresourced state structures. ${ }^{26}$ Nicholas Stockton makes the point that the central emphasis of the developmentalist, local 'capacity-building' approach of many NGOs was the assumption that the root cause of the problems of conflict or of development could only be found and resolved by long-term locally-involved NGO work. ${ }^{27}$ This ignored the international context of conflict and economic restrictions and tended to lay responsibility on the non-Western state and its citizens. ${ }^{28}$

Nicholas Leader suggests that their involvement in long-term development work in the 1970s and 1980s shaped the approach of many NGOs' to providing relief in conflict situations. A tendency developed for field staff to look for frameworks, which would allow them to address the root causes of conflict not just symptoms. He also suggests that, at a more cynical level, in the context of donor withdrawal, this enabled access to more funding by working on multiple ends. ${ }^{29}$ Today, instead of the shortterm approach of providing aid to victims of conflict, many NGOs assert that: 'There is a need to re-focus policies so that they enhance the capacity of humanitarian agencies to prevent, mitigate and resolve the effects of violent conflict' ${ }^{30}$

Joanne Macrae argues that 'humanitarianism strikes at the heart of the professional culture of developmentalists'. 31 The anti-state approach and basis of 'sustainable approaches' is hostile to short-term relief. Developmentalists argue that relief creates 
dependency and reduces the capacity of local communities, while long-term developmental support builds capacity. Macrae sees the 'neo-peaceniks', the conflict resolution and civil society-building NGOs, as posing a similar critique of humanitarian aid as a barrier to 'capacity-building'. She makes the point that these critiques miss the point that humanitarian relief was never claimed to play a role in conflict resolution or sustainable development. ${ }^{32}$ The engagement with "political and social engineering' may aim to address the causes of suffering but this level of direct and long-term interference has little to do with the emergency relief of needs-based humanitarian aid. ${ }^{33}$

By the end of the 1990s, those activists who still argued for the prioritisation of emergency relief were forced on to the defensive by the domination of the developmentalist approach. As Max Boot argued in the influential journal Foreign Affairs:

Interventions such as these [Somalia and Haiti] that address symptoms (famine or repression, for example) instead of their causes (such as bad government) are doomed to disappoint. This is a lesson the Clinton administration learned belatedly in Kosovo and Bosnia, and perhaps even in Iraq. ${ }^{34}$

\section{The human rights 'victim'}

The sphere of NGO goal-orientated rights-based humanitarianism set up crucial practical precursors for more direct and invasive government-led human rights-based interventionism of the late 1990s. It also established an ideological framework, of the relationship between Western institutions and the Third World, which become crucial to the legitimation of 'ethical' foreign policy. This framework enabled the Cold War system of international regulation to be reshaped on the basis of 'capacity-building' and rights protection. In this framework non-Western governments tended to be seen as a potential threat to their states' economic and social development, incapable of rational policy-development and prone to corruption and nepotism. The citizens of non-Western states were seen as easily manipulated by their corrupt and inefficient elites and ill-versed in the skills of political decision-making and economic exchange. Both the 'soldarity' NGOs, with a deeper commitment to international involvement in conflict resolution, and the 'developmental' NGOs tended to portray the non-Western subject as needy and incapable of self-government and in need of long-term external assistance.

This approach led relief agency guides to take visitors to the worst places, stressing the dependence of the people on outside support and making exaggerated dire predictions of the future. Journalists and media editors knew in advance what a 'humanitarian story' looked like. The overall plot has been characterised by Benthall as a moral 'fairy story, ${ }^{35}$ This 'fairy story' had three components, familiar because they are the essence of the human rights intervention 'stories' of the present. The first component is the hapless victim in distress, in the famine 'fairy story' this victim was always portrayed through film of the worst cases of child malnutrition in the worst feeding centres, in cases of civil conflict the victims are often war-refugees which have been 'ethnically-cleansed'. The second component was the villain, the nonWestern government or state authorities, which have caused famine and poverty by their personal corruption or wrong spending policies, or have consciously embarked 
on a policy of genocide or mass repression. The third component in the humanitarian 'fairy tale' was the saviour, the aid agency, the international institution or even the journalists covering the story, the saviour was an external agency whose interests were seen to be inseparable from those of the deserving victim.

The search for victims has dominated media coverage of humanitarian crises. The Kosovo crisis, for example, saw journalists "impatient to find a "good" story - i.e. a mass atrocity'. ${ }^{36}$ Many Western journalists were dispatched to Macedonia and Albania with the sole purpose of finding a rape victim, Benedicte Giaever of the OSCE was angered that 'almost every journalist who came to see her asked one thing: could she give them a rape victim to interview'. ${ }^{37}$ This approach, which takes the humanitarian crisis out of a political context to tell a 'fairy tale' or moral story has been termed the 'journalism of attachment'. This style of journalism has been forcefully critiqued:

Far from raising public understanding of the horrors of war, their reports mystify what conflicts are really about. By abstracting acts of violence from any wider conflict over political aims, they remove any possibility of people seeing what caused the war. The result of imposing a ready-made Good v Evil framework on every situation is that conflicts can only be understood as the consequence of man's atavistic, bestial urges. Instead of 'humanising' a war, this approach ultimately dehumanises all those involved... ${ }^{38}$

Alex de Waal terms the outlook of the international humanitarian agencies, and media promotion of their cause, 'disaster tourism'; in humanitarian crises they selectively saw the worst and assumed the worst. ${ }^{39}$ The lack of knowledge of the severity of the famine, drought or civil conflict led to exaggerated predictions of the death toll, and, of course, the need for support for the agency's declared rights-based humanitarian aims. The predominant approach of humanitarian interventionists to the conflicts in former Yugoslavia and Rwanda demonstrates the dangers inherent in this perspective. The humanitarian NGOs have explained the civil conflicts as events in and of themselves, from which it can only be concluded that the people of these regions are uncivilised, prone to violent and savage ethnic passions or at the very least easily manipulated by government propaganda because they lack independent critical faculties. ${ }^{40}$

The campaigning human rights-based NGOs did much to problematise the nonWestern state and legitimise Western activism through the creation of the incapable human rights victim. As Pierre Krähenbuhl notes:

The legitimacy of the humanitarian gesture is intimately connected with the ability to consider the "other", the person in need, as a human being, something which the repeated use of the expression "victim" tends to make more difficult. It strips of all human dignity the man, woman or child whom it is supposed to define. ${ }^{41}$

While Cold War power-politics tarnished the idea of 'human-centred' state-led human rights activism, the campaigning and aid NGOs revived the concept of 'ethical' Western involvement in humanitarian issues. As the late John Vincent noted: 'There is one sense, however, in which the arrival of the issue of human rights in 
international society may be regarded as wholly progressive. It is the sense in which the idea of human rights is borne by non-governmental organizations who act in defence of no sectional interest. ${ }^{42}$

With the end of the Cold War the 'geo-political straitjacket' was removed and humanitarian agencies and human rights advocacy groups seized the opportunity to influence the international agenda. ${ }^{43}$ The agencies that were able to do this most successfully were those that clearly pursued rights-based 'new humanitarianism' and rejected the post-1945 humanitarian aid framework of ICRC neutrality and needsbased emergency relief, which was tied to respect for state sovereignty rather than human rights protection. The NGOs made the running in the new order because they were less bound by either official mandates or Cold War orientations than international institutions. The lack of legal mandate and organisational flexibility has meant that it has been easy to adapt their perspective to be in tune with the times. The major exception to this shift has been the International Committee of the Red Cross, the only international relief organisation, apart from the UNHCR, tied to a mandate under international law (the Geneva Convention regulations).

This was a new sort of humanitarianism, which instead of operating separately from political mechanisms, saw itself as an alternative guide to policy-making. Far from being neutral in relation to the aspirations of both Soviet Communism and US-led market-economies, both these perspectives were seen to be flawed because they put politics above people. The language of human rights was the perfect foil for advocating an NGO-led approach. Rejecting the political Cold War framework and the narrow strategic concerns of geo-political strategy, the immediate situation of the victims was held to be all that mattered. Michael Ignatieff quotes the disillusion of Don McCullin, a British war photographer:

But what are my politics? I certainly take the side of the underprivileged. I could never say I was politically neutral. But whether I'm of the Right or the Left - I can't say... I feel, in my guts, at one with the victims. And I find there's integrity in that stance. ${ }^{44}$

Ignatieff astutely notes that this approach is a 'weary world away from the internationalism of the 1960s' when there was a political cause at stake and conflict and interventionism could be supported or opposed on the basis of Left and Right. Today, he states 'there are no good causes left - only victims of bad causes' ${ }^{45}$ Once political change in non-Western states is seen to be a flawed and pointless exercise, the only sympathy is for victims: 'the twentieth-century inflection of moral universalism has taken the form of an anti-ideological and anti-political ethic of siding with the victim; the moral risk entailed by this ethic is misanthropy'. ${ }^{46}$ This approach risks 'misanthropy' because the human rights activist sees little that is positive in the societies in which they work only passive victims and evil or dangerous abusers.

On the basis of the incapacity of the human rights victim, the 'deepening' and 'broadening' of humanitarianism is often proclaimed to be a radical and progressive approach. Yet, in many cases, the transition from needs-based to rights-based humanitarianism is a striking example of this 'ethical misanthropy'. The extension of humanitarian action is driven by the liberal conviction that the non-Western state concerned lacks an adequate capacity for self-determination or self-government. From 
short-term emergency aid, the humanitarian impulse has been transformed into a framework of long-term involvement, assistance and capacity-building. ${ }^{47}$ This is reflected in the expanded UN agendas on peace and development and the SecretaryGeneral's Millennium Report which advocate long-term social and political engineering rather than traditional grants of aid or the placement of UN 'blue helmets' to keep armies apart and monitor the peace. ${ }^{48}$

There are three inter-related reasons for this transformation in the relationship of humanitarian assistance. Firstly, the demise of social and political movements, which supported the cause of Third World independence and highlighted the inequalities of power inherent in the world market, has led to an increasingly localised focus on conflict and social problems, in isolation from the international political and economic context. Secondly, once the questions of humanitarian crisis were interpreted predominantly from a local as opposed to an international standpoint, the failure of Southern developmental strategies was seen as rooted in problems of the culture or mentality of non-Western political leaders and peoples. Thirdly, this diminished view of the non-Western subject then meant that humanitarian actors increasingly saw the involvement of themselves, and their Western government backers, as necessary for long-term political, economic and cultural change.

For some commentators the transition to rights-based humanitarianism is seen as an extension of the needs-based approach. This is clearly indicated in the terminology of 'deepening' and 'broadening' humanitarian action. The misanthropic side to this development is drawn out further in the following section, which highlights the danger that rather than supplementing traditional humanitarianism, rights-based intervention can lead to the 'ethical' justification for subordinating universal humanitarian needs to selective political ends.

\section{From humanitarian needs to human rights}

The 'deepening' and 'broadening' of humanitarianism brought into question the central principles informing the work of the ICRC. Nicholas Leader notes that with the principle of impartiality the ethical basis for humanitarian action was clear, that is based on need and given in proportion to the need. ${ }^{49}$ Once the range of humanitarian assistance was expanded the ethical basis of NGO intervention became human rights not human needs. The transformation of humanitarian work through the displacement of needs by rights has been crucial to the 'new humanitarian' discourse.

\section{Neutrality}

Human rights advocates, like Geoffrey Robertson QC, have led the calls for the reform of international humanitarian mechanisms, railing against the 'obsessive neutrality ingrained in UN personnel and procedures'. ${ }^{50}$ As Michael Ignatieff notes, 'the doctrine of neutrality has become steadily more controversial as the new politics of human rights has entered the field' ${ }^{51} \mathrm{He}$ criticises the fact that the ICRC chooses to still 'go by the book' with its narrow adherence to the Geneva Convention, and sides with its critics in MSF which highlight the ICRC's conservative 'legalistic bias' and 'cautious, lawyerly neutrality'. ${ }^{52}$ The modern human rights approach sees conflict in non-Western states not as a consequence of economic, political and social tensions, to be ameliorated by aid, but as a relationship of abuse. For every act of abuse, there are 
victims to be supported and abusers who must be punished: '[H]umanitarian intervention cannot be impartial between the Serb militiaman and the Muslim civilian, or the machete-wielding Hutu and the Tutsi victim. The ICRC's doctrine of discretion and silence... has shaded into complicity with war crimes'. ${ }^{53}$

As Jean Pictet noted: 'One cannot be at one and the same time the champion of justice and of charity. One must choose, and the ICRC has long since chosen to be a defender of charity. ${ }^{54}$ The prioritisation of neutral aid over political and social engineering has been condemned by the Red Cross's radical competitors. As merely a 'champion of charity', the ICRC is seen to be highly conservative and out of touch. ${ }^{55}$ Today, surveys of humanitarian relief organisations show that their officers agree with the shift away from political neutrality. As Hugo Slim has noted after consulting all the UK's main agencies in the field 'neutrality has almost become a dirty word'. Emma Bonino, European Commissioner for Humanitarian Affairs, noted in a September 1998 panel discussion that: 'I have my doubts...that being neutral is still at all possible, or indeed ethically just'. In a forceful critique she questions whether it is feasible that humanitarian agencies 'should be unable to distinguish right from wrong, the aggressor from the victim, the killers from the dead bodies? What absurd wisdom could call for this organised ethical confusion'. ${ }^{56}$ A recent Caritas Europa discussion paper notes: 'Today neutrality is seen as undesirable. Either because it's considered amoral - remaining silent in the face of human rights abuses - or, simply because the central role of NGOs in highly political emergencies makes it impossible to achieve'. ${ }^{57}$

The 'new humanitarian' NGOs have a very different approach to the principle of neutrality and see their role as an engaged and radical one, aiming to fundamentally transform non-Western societies to tackle the underlying causes of violence. The 1990s codes for humanitarian conduct tend to avoid the commitments to strict neutrality of the ICRC. In the Providence Principles 'neutrality' is replaced by 'nonpartisanship' while the Code of Conduct simply states that 'aid will not be used to further a particular political or religious standpoint'. ${ }^{58}$ While agencies like Oxfam, Save the Children and UNICEF have all adopted a 'new humanitarian' approach in recent years, the leading advocate of the new human rights-based humanitarianism is Médecins Sans Frontières. Alain Destexhe, former MSF General-Secretary argues: 'Humanitarian action is noble when coupled with political action and justice. Without them, it is doomed to failure'. ${ }^{99}$ The award of the Nobel Peace Prize to MSF, in 1999, was a highly significant statement in support of the transition to rights-based humanitarian aid. This was acknowledged by the agency's founder Bernard Kouchner: 'MSF's work was political from the start. I hope the prize marks the recognition of a type of humanitarian work which fights injustice and persecution, in contrast to traditional organisations.' 60

\section{Universalism}

During the 1990s, humanitarian aid organisations have come under fire if they have followed a universalist approach of providing emergency aid solely on the basis of need rather than policy ends. It is now commonplace to read of humanitarian aid prolonging wars, feeding killers, legitimising corrupt regimes, creating war economies and perpetuating genocidal policies. Humanitarians have gone from being angels of mercy who can do no wrong to being seen as part of the problem. The British 
Secretary of State for International Development, Claire Short, has expressed concerns that aid agencies have prolonged the conflict in Sudan and has said she is 'haunted by the risk of relief maintaining conflict'. ${ }^{61}$ Similarly, the European Community's Humanitarian Office (ECHO) has decided to shift to a new human rights-based approach to humanitarian aid, as a result of sustained criticism: 'Business as usual for the Commission as humanitarian aid donor would mean courting the risk of growing criticism and isolation from the donor community, and a loss of credibility generally'.62

The trend was highlighted by the controversy over the delivery of aid to the nearly two million Rwandan refugees in camps in Ngara, Goma and Bukava in Zaire, in 1996. From the very beginning, agencies were condemned by human rights groups for saving the lives of 'genocidaires' who would survive to reorganise and re-invade Rwanda to 'finish-off' the genocide. ${ }^{63}$ As James Orbinski stated on receiving the Nobel Peace Prize for MSF:

The moral intention of the humanitarian act must be confronted with its actual result. And it is here where any form of moral neutrality about what is good must be rejected. The result can be the use of the humanitarian in 1985 to support forced migration in Ethiopia, or the use in 1996 of the humanitarian to support a genocidal regime in the refugee camps of Goma. Abstention is sometimes necessary so that the humanitarian is not used against a population in crisis. ${ }^{64}$

This perspective is often termed the 'Do No Harm' approach in which not providing aid to those in need is ethically defensible through the human rights discourse. ${ }^{65}$ Short-term assistance is criticised for the potential long-term harm, either in fuelling conflict or legitimising and strengthening political factions. ${ }^{66}$ The result of this approach was the deaths of up to 200,000 people in Zaire, fleeing troops clearly intent on revenge for the genocide of $1994 .{ }^{67}$ Oxfam's Acting Policy Director, Nick Bloomer, has attempted to challenge the 'trend to start blaming humanitarian assistance for the conflicts'. He has warned that: 'We've seen a concerted political attack on the fundamental humanitarian principles and assistance for perpetuating wars' ${ }^{68}$ By no means all refugees were guilty of genocide. As Nicholas Stockton notes, some 750,000 forcibly repatriated or 'lost in Zaire' were children under five, over 1.5 million were under 16 years of age. ${ }^{69}$ He concludes that: 'The application of 'do no harm' is tantamount to playing God - a deadly, perhaps totalitarian business to indulge in without the benefit of 20:20 future vision' ${ }^{70}$

This perspective of subjecting humanitarian aid to human rights conditions has, since the Rwandan crisis, become the official UK government position. Tess Kingham MP, a member of the International Development Committee, argues:

Surely taking a view of the wider good - for the long term interests of people - to actually achieve real stability and development, that it may be better to withdraw aid now - to ensure that in the long term, it is in the best interests of the people. ${ }^{71}$

Attaching conditions to humanitarian relief on the basis of human rights objectives has brought into question the universal right of every man, woman and child to relief 
at times of disaster, which is enshrined in international law. The 'new humanitarian' approach of blaming the 'undeserving victims' has led to support for sanctions and the refusal of aid. For example, Geoffrey Robertson argues that sanctions on post-war Serbia are justified because 'most of Serbia's eight million citizens were guilty of indifference towards atrocities in Kosovo'. 72

The redefinition of humanitarianism and the shift away from universalism and neutrality has questioned the internationally accepted framework of international humanitarian assistance. The mitigation of human suffering is no longer the priority for international human rights-based humanitarianism. While withholding development aid until certain conditions are met is common practice, the application of this principle to humanitarian aid is a dramatic departure from traditional policy. The notion of withholding emergency aid from people in dire need is an unprecedented attack on humanitarian values and practices.

\section{Conclusion}

Once humanitarian intervention is conflated with rights-based strategic ends, these political ends are redefined as ethical and used to justify the denial of humanitarian principles. Over the last decade the universal humanist core of humanitarian action has been undermined and humanitarianism has become an ambiguous concept capable of justifying the most barbaric of military actions. Today, leading commentators suggest that 'there is no general definition of humanitarianism' or ask 'What on earth does the word "humanitarian" mean?'. ${ }^{73}$ As Peter Fuchs, the Director General of the ICRC has stated: 'the respective roles of politicians, generals and humanitarian actors are not clear anymore'. ${ }^{74}$ Humanitarian militarism, widely advocated during the 1999 Kosovo war, would have been an oxymoron before the 1990s, today it has become a tautology.

The traditional image of humanitarian assistance, of sending food parcels and blankets or granting asylum to refugees is today seen as a problem precisely because it is humanitarian: because it does not concern itself with a human rights solution beyond meeting immediate need. Gil Loescher, for example condemns the UNHCR precisely for its narrow humanitarianism:

A major obstacle to taking a more active role in refugee protection in countries of origin derives from the international refugee regime itself. The UNHCR was designed to appear to be non-political and strictly humanitarian... UNHCR, as it is presently structured, is not mandated to intervene politically against governments or opposition groups... ${ }^{75}$

The UNHCR, along with other humanitarian agencies, is being pressurised into redefining its role in crisis situations. Reflecting the 'new humanitarian' consensus, the UNHCR is downplaying its humanitarian role of aiding refugees, and taking on a new, more invasive role as a human rights actor assuming the rights and responsibilities of dealing with the root causes of refugee problems. ${ }^{76}$

Ironically, the strongest critique of needs-based humanitarian action is from the human rights movement itself, which argues that responding to crises by sending humanitarian relief is merely an excuse to avoid 'more vigorous responses'. 77 
Humanitarian relief is increasingly seen as giving Western governments the appearance of 'doing something' in the face of a tragedy while providing an alibi to avoid making a riskier political or military commitment that could address the 'roots of a crisis' ${ }^{78}$ The advocates of human rights-based foreign policy are in the forefront of the campaign against humanitarian approaches. Under the slogan that 'humanitarianism should not be used as a substitute for political action' they are in fact arguing for a rights-based humanitarianism that is entirely subordinate to policy ends. $^{79}$

Today, instead of feeding famine victims, aid may well be cut back as the UK government has done over Sudan and Ethiopia. ${ }^{80}$ Human rights advocates would seem to be happier with military intervention and the establishment of 'safe areas' rather than granting asylum which is seen as legitimising 'ethnic cleansing. ${ }^{81}$ As journalist David Rieff notes: 'humanitarian relief organizations... have become some of the most fervent interventionists ${ }^{82}$ Thomas Weiss observes the human rights community have redefined humanitarianism as its opposite: 'These actions are, by definition, coercive and partial. They are political and humanitarian; they certainly are not neutral, impartial, or consensual, ${ }^{83}$

The restrictions on humanitarian aid and universal charity means that those dependent on aid have even less opportunity for autonomy than previously. In Bosnia, human rights NGOs like the International Crisis Group (ICG) have lobbied strongly for economic aid to be conditional on the implementation of the Dayton Accords and have argued that aid conditionality is the main source of leverage for the international Community ${ }^{84}$ In Serbia, European Union humanitarian aid programmes operate on the highly selective basis of providing fuel and provisions to opposition-run municipalities while applying strict sanctions to the rest of the country. This has been challenged by the UN Office for the Co-ordination of Humanitarian Affairs in Belgrade and the International Federation of the Red Cross, which argue that aid should be given on the basis of need and irrespective of political party affiliation. ${ }^{85}$ The politicisation of humanitarian aid has led to even greater leverage over nonWestern societies as NGOs and international institutions increasingly assume the right to make judgements about what is right and just, about whose capacities are built and which local groups are favoured. Where humanitarian aid started out as an expression of empathy with common humanity it has been transformed through the discourse of human rights into a lever for strategic aims drawn up and acted upon by external agencies.

From being based on the universal nature of humanity, which inevitably caused conflict with the pro-Western agenda of the Cold War, today's 'new humanitarians' have challenged every principle that demarcated the traditional framework of humanitarian action. No longer do they advocate a principled neutrality, nor defend the most basic level of humanitarian relief as a universal right if this threatens to undermine broader strategic human rights-based aims. Through the human rights discourse, humanitarian action has become transformed from relying on empathy with suffering victims and providing emergency aid, to mobilising misanthropy and legitimising the politics of international condemnation, sanctions and bombings.

\section{Notes}


1. D. Warner, The Politics of the Political/Humanitarian Divide, INTERNATIONAL REVIEW OF THE RED CROSS, No.833, 1999, pp.109-18.

2. Cited in $I d$.

3. Cited in L. Minear, The Theory and Practice of Neutrality: Some Thoughts on the Tensions, INTERNATIONAL REVIEW OF THE RED CROSS, No.833, 1999, pp.63-71.

4. M. IGNATIEFF, THE WARRIOR'S HONOR: ETHNIC WAR AND THE MODERN CONSCIENCE, London: Chatto \& Windus, 1998, at 119.

5. B. WHITTAKER, A BRIDGE OF PEOPLE, London: Heinemann, 1983, at 11.

6. H. Searls, The NGO Revolution, unpublished discussion paper, 1995.

7. B. Nicholls, Rubber Band Humanitarianism, ETHICS AND INTERNATIONAL AFFAIRS, No.1, 1987, pp.191-210 at 195.

8. N. Leader, (1998) Proliferating Principles; Or How to Sup With the Devil Without Getting Eaten, DISASTERS, Vol.22, No.4, 1998, pp.288-308, at 295.

9. World Council of Churches - Programme on Humanitarian Assistance, The Mohonk Criteria for Humanitarian Assistance in Complex Emergencies, Geneva: World Council of Churches, 1993.

10. Leader, supra note 8, at 298.

11. A. DE WAAL, FAMINE CRIMES: POLITICS AND THE DISASTER RELIEF INDUSTRY IN AFRICA, Oxford: James Curry/ Indiana University Press, 1997. T. G. Weiss, Principles, Politics and Humanitarian Action, ETHICS AND INTERNATIONAL AFFAIRS, Vol.13, 1999, pp.1-22, at 3.

12. Cited in WAAL, supra note 11 at 75.

13. Id. at 76 .

14. J. Orbinski, The Nobel Lecture by the Nobel Peace Prize Laureate 1999: Medecins Sans Frontieres, 10 December, 1999. Available from $<$ http:www.nobel.no/msf_1999eng.html $>$.

15. D. Rieff, Humanitarian Intervention, in R. Gutman and D. Rieff (eds) CRIMES OF WAR: WHAT THE PUBLIC SHOULD KNOW, New York: W. W. Norton, 1999, pp.181-4, at 184; M. Pugh, Military Intervention and Humanitarian Action: Trends and Issues, DISASTERS, Vol.22, No.4, 1998, pp.339-351, at 341.

16. Cited in Leader, supra note 8 at 297.

17. Pugh, supra note 15 at 340.

18. WHITTAKER, supra note 5 at 21.

19. Searls, supra note 6 .

20. D. P. FORSYTHE, HUMAN RIGHTS AND WORLD POLITICS ( $2^{\text {nd }}$ edition), Lincoln and London: University of Nebraska Press, 1989, at 27.

21. WHITTAKER, supra note 5 at 51 .

22. WAAL, supra note 11 at 65 .

23. D.KORTEN, GETTING INTO THE $21^{\text {ST }}$ CENTURY: VOLUNTARY ACTION AND THE GLOBAL AGENDA, West Hartford: Kumarian Press, 1990, at 95.

24. R. Palmer and J. Rossiter, cited in Searls, supra note 6.

25. M. Edwards and D. Hulme, NGOs and Development: Performance and Accountability in the New World Order. Background paper for international workshop 'NGOs and Development: Performance and Accountability in the New World', University of Manchester, 27-29 June, 1994.

26. S. D. Burgerman, Mobilizing Principles: The Role of Transnational Activists in Promoting Human Rights Principles, HUMAN RIGHTS QUARTERLY, Vol.20, 1998, pp.905-923, at 905. 
27. N. Stockton, In Defence of Humanitarianism, DISASTERS, Vol.22, No.4, 1998, pp.352-360, at 355.

28. N. MIDDLETON AND P. O'KEEFE, DISASTER AND DEVELOPMENT: THE POLITICS OF HUMANITARIAN AID, London: Pluto Press, 1998; M. Duffield, The Symphony of the Damned: Racial Discourse, Complex Emergencies and Humanitarian Aid, DISASTERS, 1996, Vol.20, No.3, pp.173-193.

29. Leader, supra note 8 at 297.

30. Goodhand and Hulme, cited in Id. at 297.

31. J. Macrae, The Death of Humanitarianism?: An Anatomy of the Attack, DISASTERS, Vol.22, No.4, 1998, pp.309-317 at 312.

32. Id. at 314.

33. Pugh, supra note 15 at 340 .

34. M. Boot, Paving the Road to Hell (Book Review): The Failure of UN Peacekeeping, FOREIGN AFFAIRS, Vol.79, No.2, 2000, pp.143-8.

35. Cited in WAAL, supra note 11 at 82-3.

36. A. Gillan, The Propaganda War, GUARDIAN, 21 August, 2000.

37. Id.

38. M. HUME, WHOSE WAR IS IT ANYWAY, London: Informinc, 1997, at 15.

39. WAAL, supra note 11 at 82.

40. See for example, F. Hartmann, Bosnia, in R. Gutman and D. Rieff (eds) CRIMES OF WAR: WHAT THE PUBLIC SHOULD KNOW, New York: W. W. Norton, 1999, pp.50-56, at 54; and, for a critique, B. COLLINS, OBEDIENCE IN RWANDA: A CRITICAL QUESTION, Sheffield: Sheffield Hallam University Press, 1997.

41. P. Krähenbuhl, Conflict in the Balkans: Human tragedies and the challenge to independent humanitarian action, INTERNATIONAL REVIEW OF THE RED CROSS, No.837, March, 2000, pp.11-29.

42. R. J. Vincent, Conclusion, in R. J. Vincent (ed.) FOREIGN POLICY AND HUMAN RIGHTS: ISSUES AND RESPONSES, Cambridge: Royal Institute of International Affairs/ Cambridge University Press, 1986, pp.261-5, at 264.

43. WAAL, supra note 11 at 133.

44. IGNATIEFF, supra note 4 at 23.

45. Id.

46. Id. at 25 .

47. J. Mackinlay and R. Kent, A New Approach to Complex Emergencies, INTERNATIONAL PEACEKEEPING, Vol.4, No.4, 1997, pp.31-49; B. C. Hayes and J. I. Sands, Non-Traditional Military Responses to End Wars: Considerations for Policymakers, MILLENNIUM, Vol.26, No.3, 1997, pp.819-844; R. Paris, Peacebuilding and the Limits of Liberal Internationalism, INTERNATIONAL SECURITY, Vol.22, No.2, 1997, pp.54-89.

48. An Agenda for Peace: Preventive Diplomacy, Peacemaking and Peace-keeping, Report of the Secretary-General (A/47/277-S/24111), 17 June, 1992; An Agenda for Development, Report of the Secretary-General (A/48/935), 6 May, 1994; Supplement to an Agenda for Peace: Position Paper of the Secretary-General on the Occasion of the Fiftieth Anniversary of the United Nations (A/50/60S/1995/1), 3 January, 1995; "We the Peoples": The Role of the United Nations in the $21^{\text {st }}$ Century, Millennium Report of the Secretary-General (A/54/2000), New York: United Nations, 2000. Available from: $<$ http://www.un.org/millennium/sg/report>.

49. Leader, supra note 8 at 298. 
50. G. ROBERTSON, CRIMES AGAINST HUMANITY: THE STRUGGLE FOR GLOBAL JUSTICE (revised edition), London: Penguin Books, 2000, at xix.

51. IGNATIEFF, supra note 4 at 119.

52. M. Ignatieff, International Committee of the Red Cross (ICRC), in R. Gutman and D. Rieff (eds) CRIMES OF WAR: WHAT THE PUBLIC SHOULD KNOW, New York: W. W. Norton, 1999, pp.202-4, at 203-4.

53. IGNATIEFF, supra note 4 at 124.

54. Cited in Minear, supra note 3.

55. J. F. HUTCHINSON, CHAMPIONS OF CHARITY: WAR AND THE RISE OF THE RED CROSS, Boulder: Westview, 1996.

56. Cited in Minear, supra note 3.

57. F. Fox, The Politicisation of Humanitarian Aid, draft discussion paper for Caritas Europa, 1999.

58. Leader, supra note 8 at 299.

59. Cited in Weiss, supra note 11 at 15.

60. Cited in Fox, 1999 supra note 57.

61. Id.

62. Id.

63. WAAL, supra note 11 at 195; Stockton, supra note 27 at 353.

64. Orbinski, supra note 14.

65. Macrae, supra note 31 at 312 .

66. Leader, supra note 8 at 304-5.

67. Stockton, supra note 27 at 353.

68. P. Bloomer, The Chronicle Interview, UN CHRONICLE, Vol.36, No.2, 1999, pp.18-21, at 20.

69. Stockton, supra note 27 at 354 .

70. Id. at 356 .

71. Cited in Fox, supra note 57.

72. Robertson, supra note 50 at 417.

73. O. RAMSBOTHAM, AND T. WOODHOUSE, HUMANITARIAN INTERVENTION IN CONTEMPORARY CONFLICT: A RECONCEPTUALIZATION, Cambridge: Polity Press, 1996, at 9.

74. P. Fuchs, Handling Information in Humanitarian Operations Within Armed Conflicts, $1999 . \quad$ Available from: http://www.osi.net/Proceedings/ossaaa/aaa4/aaa4ae.

75. G. Loescher, Refugees: a Global Human Rights and Security Crisis, in T. Dunne and N. J. Wheeler (eds) HUMAN RIGHTS IN GLOBAL POLITICS, Cambridge: Cambridge University Press, 1999, pp.233-258, at 241.

76. D. P. FORSYTHE, HUMAN RIGHTS IN INTERNATIONAL RELATIONS, Cambridge: Cambridge University Press, 2000, at 74.

77. T. G. Weiss, The Politics of Humanitarian Ideas, SECURITY DIALOGUE, Vol.31, No.1, 2000, pp.11-23, at 14.

78. See for example, A. Roberts, The Role of Humanitarian Issues in International Politics in the 1990s, INTERNATIONAL REVIEW OF THE RED CROSS, No.833, 1999, pp.19-43.

79. Stockton, supra note 27 at 356.

80. A. McSmith and J. Burke, Britain Slashes Aid to Ethiopia, OBSERVER, 9 April, 2000; For Our Sake, Don't Cut Third World Aid, Editorial, OBSERVER, 9 April, 2000.

81. Roberts, supra note 78. 
82. Rieff, supra note 15 at 184.

83. Weiss, supra note 11 at 21.

84. Pugh, supra note 15 at 343; D. CHANDLER, BOSNIA: FAKING DEMOCRACY AFTER DAYTON, London: Pluto Press, 1999.

85. L. K. Rozen, Humanitarian Aid, BOSTON GLOBE, 30 July, 2000; L. K. Rozen, Bread instead of Soldiers, SALON, 7 August, 2000. Available from: $<$ http://www.salon.com/news/feature/2000/08/07/aid/index.html>. 